\title{
Severity of Scab and its Effects on Fruit Weight in Mechanically Hedge-Pruned and Topped Pecan Trees
}

Clive H. Bock and Michael W. Hotchkiss, USDA-ARS-SEFTNRL, Byron, GA 31008; Tim B. Brenneman and Katherine L. Stevenson, University of Georgia, Tifton 31793; William D. Goff, Auburn University, Auburn, AL; Michael W. Smith, Oklahoma State University, Stillwater 74078; Lenny Wells, University of Georgia, Tifton 31793; and Bruce W. Wood, USDA-ARS-SEFTNRL

\begin{abstract}
Scab is the most damaging disease of pecan in the southeastern United States. Pecan trees can attain $44 \mathrm{~m}$ in height, so managing disease in the upper canopy is a problem. Fungicide is ordinarily applied using ground-based airblast sprayers. Although mechanical hedge-pruning and topping of pecan is done for several reasons, improved management of scab is an important reason in the humid, wet Southeast. Resulting shoot growth on cut limbs of susceptible cultivars could lead to more severe scab. In three experiments over three years, we explored the effect of hedge-pruning trees to $\sim 12$ to $14 \mathrm{~m}$ compared with non-hedge-pruned trees. All trees received fungicide treatments (air-blast sprays and $\leq 3$ aerial applications). Hedge-pruning either had no effect, or increased or decreased scab severity only slightly on leaflets,

immature, or mature fruit (a -9.95 to $+14.63 \%$ difference in scab severity compared with the control). However, height in the canopy invariably had a large and significant effect on scab severity, and amounted to a 0.05 to $73.77 \%$ difference in severity between the lowest and highest sample in the canopy. Fruit weight depended on sample height, with fruit most often weighing less when collected at greater sample heights. A robust relationship between fruit weight and scab severity was found at the highest sample heights where scab was also most often severe $\left(\mathrm{R}^{2}=0.21\right.$ to $0.67, P<$ 0.0001 ). Hedge-pruning and topping pecan tree canopies to manage tree size will enable better fungicide coverage, reducing risk of a scab epidemic as more of the canopy is assured efficacious fungicide spray coverage.
\end{abstract}

Scab (caused by Fusicladium effusum G. Winter) is the most destructive disease of pecan (Carya illinoinensis [Wangenh.] K. Koch). The pathogen reproduces by splash- and wind-dispersed conidia (Gottwald and Bertrand 1982) that require surface wetness for germination and infection to occur (Gottwald 1985; Turechek and Stevenson 1998). In areas where rainfall occurs during the growing season (including the southeastern United States, parts of South America, and South Africa), scab can cause substantial yield loss (Goff and Miller 1978; Gottwald and Bertrand 1982, 1983; Stevenson and Bertrand 2001). Both foliage and fruit are susceptible to infection. Foliage susceptibility is greatest during leaf expansion, but mature leaves are effectively resistant (Gottwald 1985; Turechek and Stevenson 1998). Fruit remains susceptible even when fully mature, and disease on fruit has the greatest impact on yield.

Various methods have been used to manage the disease including development of resistant cultivars, many of which have become susceptible (Goff et al. 1996) due to the pathogen's adaptability and variability (Bock et al. 2014; Conner and Stevenson 2004; Converse 1960). Many growers continue to plant cultivars that are susceptible to scab (Wells 2014); thus, the disease continues to be an issue. Modern fungicides are available, but unfortunately there is a history of resistance developing to certain classes of fungicide used to control pecan scab (Littrell 1976; Stevenson 1999; Stevenson et al. 2014), which can limit their efficacy.

Pecan trees can exceed $44 \mathrm{~m}$ in height (Stone 1997), and scab occurs at all heights in the canopy (Bock et al. 2013). Understanding disease distribution in the canopy is required to ensure efficacious management. Untreated pecan trees tend to have more severe scab at lower heights in the canopy (although not invariably so) (Bertrand and Brenneman 2001; Bock et al. 2013). However, trees sprayed

Corresponding author: Clive H. Bock; E-mail: clive.bock@ars.usda.gov

*The $\boldsymbol{e}$-Xtra logo stands for "electronic extra" and indicates that two supplementary figures and five supplementary tables are available online.

Accepted for publication 12 December 2016.

This article is in the public domain and not copyrightable. It may be freely reprinted with customary crediting of the source. The American Phytopathological Society, 2017. with fungicide using a ground-based air-blast sprayer will either have similar scab severity throughout the canopy, or will have more severe disease in the upper canopy (Bertrand and Brenneman 2001; Bock et al. 2013). Effects of air-blast sprayer applied fungicide on disease wane at approximately $12 \mathrm{~m}$ (Bock et al. 2013, 2015; Reilly et al. 2007; Sumner 2004). Similarly, there are limitations to aerially applied sprays, which are applied less frequently than ground-based sprays, and at lower volume ( 75 to 94 versus 1,000 liters/ha), resulting in less uniform coverage and consequently less efficacious disease control, except perhaps in the top of the canopy (Bertrand and Brenneman 2001; Reilly et al. 2007). Limited data available indicate that at least $50 \%$ of fruit are borne in the upper half of a canopy (LoranoGonzalez et al. 1992), where spray coverage in tall trees is least efficacious.

Demaree (1924) opined, "It is hoped that horticulturalists will devise some system of pruning that will tend to reduce the height of the trees and open up their centers so as to facilitate spraying operations." Selective limb removal was eventually recommended with one aim being disease management (Lombardini 2006; Worley 1985; Worley et al. 1996). But no data were provided that demonstrated that disease was actually reduced as a result, although pruning apple trees has been demonstrated to reduce apple scab (Holb 2005), caused by Venturia inaequalis (Cooke) G. Wint., while improving fungicide spray coverage (Travis et al. 1987). Indeed, pruning has been shown to reduce incidence or severity of various plant diseases (Holtz et al. 2002; Probst et al. 2016; Shtienberg et al. 2003). Mechanical hedge-pruning and topping of pecan has been developed and adopted in dry environments like the southwestern United States (Wood 2009). As with walnut (Olsen et al. 1974, 2003), the main purpose is to make the trees more amenable to management, and to reduce the amplitude of alternate bearing (Wood and Stahmann 2004). Hedge-pruning methods used in the Southwest depressed yields in the Southeast (Wood 2009; Worley 1985). Wood (2009) recommended that pruning be less aggressive to result in broader canopies, allowing better light penetration, and that trees be pruned on a 3 to 4 year cycle. In 2010, pecan growers reported results of some tests with modified hedge-pruning in the Southeast (Stevenson 2013), and suggested that they were a promising approach to pecan production for the region.

Shoots generated from buds laid down the previous season are most often determinate, but shoots emerging near hedge-pruning wounds are indeterminate, producing a season-long supply of young, expanding foliage (Worley 1985), which can become infected by 
F. effusum. Epidemics of scab may occur on these trees in the season after they have been hedge-pruned, even with fungicide applications. Anecdotal observations suggest scab is not exacerbated on pruned trees (Stevenson 2013). Data are needed to establish the effect as the industry already spends tens of millions of dollars annually managing pecan scab, and can suffer equivalent economic loss due to the disease (Brock and Brenneman 2015). Therefore, it is valuable to establish whether hedge-pruning increases, reduces, or has no effect on scab severity.

The main aim was to explore whether hedge-pruned trees in the Southeast might become more severely scabbed compared with non-hedge-pruned trees under a standard fungicide program. Specific objectives were to determine i) whether hedge-pruning of pecan trees influences scab severity, ii) the distribution and severity of scab and fruit weight at different heights in the tree canopy, and iii) whether relationships exist between scab severities and fruit weights at various pruning heights.

\section{Materials and Methods}

Orchard locations and management. The experiments were conducted in growers' orchards in Georgia, U.S.A. Orchards were located close to the towns of Marshallville (Macon Co., 32 $29^{\prime} 58.0^{\prime \prime} \mathrm{N}$, $83^{\circ} 55^{\prime} 55.0^{\prime \prime} \mathrm{W}$ ), Ray City (Berrien Co., $31^{\circ} 4^{\prime} 33.4^{\prime \prime} \mathrm{N}, 83^{\circ} 14^{\prime} 48.3^{\prime \prime}$ W), and Weston (Webster Co., 31 ${ }^{\circ} 57^{\prime} 55.9^{\prime \prime} \mathrm{N}, 84^{\circ} 36^{\prime} 41.2^{\prime \prime} \mathrm{W}$ ). Cultivar Desirable (highly susceptible to scab, Sparks 1992) was grown at the Marshallville and Ray City locations, and cv. Pawnee (moderately susceptible to scab, Sparks 1992) was grown at the Weston location. In 2013, both hedge-pruned and non-hedged trees at the Weston orchard were 13 years old and 12 to $14 \mathrm{~m}$ tall. At the Marshallville orchard, trees were 17 years old and both hedge-pruned and non-hedged trees were also approximately 12 to $14 \mathrm{~m}$ tall. Trees at the Ray City orchard were 25 years old in 2013, and were 18 to $20 \mathrm{~m}$ tall, unless hedge-pruned to a height of 12 to $14 \mathrm{~m}$. All orchards received irrigation, fertilizer, and weed and insect control following guidelines for standard management practices typical of pecan orchards in Georgia (Wells 2016). Fungicide sprays were applied to all three orchards to control scab. Fungicide type, timing and frequency, and method of application (ground-based air-blast sprayers or aerial applications) varied with orchard (Table 1 and Supplementary Tables S1 and S2). In all orchards, equivalent equipment (airblast sprayers and fixed-wing aircraft) was used to apply fungicides, although manufacturers varied.

Hedge-pruning treatments and experimental design. A range of mechanical hedge-pruning and topping treatments was applied at each location, and the details of timing of these treatments are provided (Table 2). In 2013 and 2014, there were five treatments in the Weston orchard: 1) no hedging (control). 2) Dormant season hedged on two sides, and in the following year the trees were hedged on the opposite two sides (cuts 12 feet from trunk). The tops were cut on hedged sides when height exceeded row width. The pattern was repeated over a 2-year period (DH2_Y_T). 3) Hedge one side of the tree each year. Also cut tops on hedged sides when height exceeded row width (H1_Y). 4) Repeat 2, except only on expected "on year" ("on year" is the year of greatest yield during the alternate bearing cycle, which is typical of many trees) (ON_DH2_Y_T). 5) Hedge 2 sides in July during the "on year." Opposite 2 sides next "on year" and every year hedge tops in May and July (ON_GH2_T2_Y). Management in the orchard changed in 2015 , and all trees were hedgepruned on one side, either the east or west row-side. Thus, in 2015, there was a comparison of hedged and non-hedged sides of trees only. The Marshallville orchard received two treatments: 1) no hedging (control), and 2) one side hedged in year 1, second side in year 2 (hedged), with the cycle repeated every 3 years. The Ray City orchard received three treatments: 1) no hedging (control);2) one side hedged in year 1 , the second side in year 2 (hedge $1 \mathrm{~S}$ ); and 3 ) both sides hedged in year 1 (hedge $2 \mathrm{~S}$ ), with the cycle occurring only

Table 1. Tree heights and spray programs applied to pecan trees in three different orchards in Weston, Marshallville, and Ray City, GA, 2013 to 2015 (details of spray programs and chemistries are provided in Supplementary Tables S1 and S2)

\begin{tabular}{lclll}
\hline & & \multicolumn{3}{c}{ Number of fungicide sprays applied (year) } \\
\cline { 3 - 5 } Experiment & Tree height $(\mathbf{m})$ & $\mathbf{2 0 1 3}$ & $\mathbf{2 0 1 4}$ & \multicolumn{2}{c}{$\mathbf{2 0 1 5}$} \\
\hline Weston cv. Pawnee & 12 to 14 & 12 (ground, all rows) & (ground, all rows) & 14 (ground, all rows) \\
Marshallville cv. Desirable & 12 to 14 & 11 (ground, all rows), 3 (air) & 10 (ground, all rows), 3 (air) & 10 (ground, all rows), 3 (air) \\
Ray City cv. Desirable & 17 to 19 & $\begin{array}{c}\text { 22 (ground, 12 all rows, 10 alternate } \\
\text { middle rows), 2 (air) }\end{array}$ & 16 (ground, all rows) & 15 (ground, all rows)
\end{tabular}

Table 2. Mechanical hedge-pruning and topping treatments applied to pecan trees in three different orchards in Weston, Marshallville, and Ray City, GA, 2012 to 2015

\begin{tabular}{|c|c|c|c|c|c|c|c|c|c|}
\hline \multirow[b]{3}{*}{ Experimenty } & & \multicolumn{8}{|c|}{ Year $^{\mathbf{Z}}$} \\
\hline & & \multicolumn{2}{|c|}{2012} & \multicolumn{2}{|c|}{2013} & \multicolumn{2}{|c|}{2014} & \multicolumn{2}{|c|}{2015} \\
\hline & & Winter & Summer & Winter & Summer & Winter & Summer & Winter & Summer \\
\hline \multirow[t]{2}{*}{ Marshallville cv. Desirable } & Control & & & & & & & & \\
\hline & Hedged & & & $\mathrm{R} 1(\mathrm{E} / \mathrm{W})$ & & $\mathrm{R} 2(\mathrm{E} / \mathrm{W})$ & & & \\
\hline \multirow[t]{5}{*}{ Weston cv. Pawnee } & Control & & & & & & & & \\
\hline & DH2_Y_T & $\mathrm{E} / \mathrm{W}$ & & $\mathrm{N} / \mathrm{S}$ & & $\mathrm{E} / \mathrm{W}$ & & & \\
\hline & H1_Y & $\mathrm{E}$ & & $\mathrm{N}$ & & W & & $\mathrm{W}$ or $\mathrm{E}$ & \\
\hline & ON_DH2_Y_T & & & $\mathrm{N} / \mathrm{S}$ & & $\mathrm{E} / \mathrm{W}$ & & & \\
\hline & ON_GH2_T2_Y & & & $\mathrm{N} / \mathrm{S}$ & $\mathrm{T}(\mathrm{M} / \mathrm{J})$ & & $\mathrm{T}(\mathrm{M} / \mathrm{J})$ & & \\
\hline \multirow[t]{3}{*}{ Ray City cv. Desirable } & Control & & & & & & & & \\
\hline & Hedge $1 \mathrm{~S}$ & & & S & & $\mathrm{N}$ & & & \\
\hline & Hedge $2 \mathrm{~S}$ & & & $\mathrm{~N} / \mathrm{S}$ & & & & & \\
\hline
\end{tabular}

\footnotetext{
${ }^{y}$ In the different experiments the treatments were as follows: Weston: control (no hedging); DH2_Y_T (dormant season hedged on two sides, following year hedged on the opposite two sides [cuts 12 feet from trunk]. Cut tops on hedged sides when height exceeds row width. Repeat the pattern over 2-year periods); H1_Y (hedge one side of the tree each year. Also cut tops on hedged sides when height exceeds row width); ON_DH2_Y_T (repeat 2, except only on expected “on year"); ON_GH2_T2_Y (hedge two sides July during "on year”. Opposite two sides next "on year" and every year hedge tops May and July). Management in the Weston orchard changed in 2015, and all trees were hedge-pruned on one side, either the east or west row-side. Thus, in 2015, there was a comparison of hedged and non-hedged sides of trees only. Marshallville: control (no hedging); hedged (one side hedged in year 1, second side year 2 with the cycle repeated on a 3-year basis). Ray City: control (no hedging); hedge 1S (one side hedged in year 1, the second side in year 2 with the cycle occurring only once); hedge $2 \mathrm{~S}$ (both sides hedged in year 1 , with the cycle occurring only once).

${ }^{\mathrm{z}} \mathrm{N}=$ north, $\mathrm{S}=$ south, $\mathrm{E}=$ east, $\mathrm{W}=$ west, $\mathrm{T}=$ tops, $\mathrm{M}=$ May, $\mathrm{J}=$ July, $\mathrm{R} 1=$ first row hedged, $\mathrm{R} 2=$ second (alternate) row hedged.
} 
once. At all locations, the hedging treatments were applied using a TH2000 Pecan Topper Hedger (Afron Picking and Pruning Solutions, Pardess-Hanna, Israel).

Depending on the experiment, samples were collected at up to four heights. Ten compound leaves and 10 fruit were collected at each height on both row-sides of each sample tree. Samples were collected using a hydraulic lift at approximately 5 to 6,8 to 9 , and 10 to $13 \mathrm{~m}$. At the Ray City orchard, in the non-hedge-pruned trees samples were also collected at 15 to $18 \mathrm{~m}$. Sample heights above ground were measured using an Opti-Logic Laser Rangefinder (Opti-Logic, Tullahoma, TN). Leaf and fruit samples were assessed for severity of pecan scab as previously described (Bock et al. 2013). The percent area diseased was visually estimated on each leaflet of each pinnately compound leaf. Scab on fruit was assessed similarly. Pecan fruit are composed of four valves joined along their edges by a suture, and each of the four valve faces was assessed individually. Assessments were aided by standard area diagrams for leaflets (unpublished diagrams) and for fruit (Yadav et al. 2013). Scab assessments were made on the dates indicated in Table 3. Fruit fresh weight was determined individually at the time of the final assessment (25 August to 10 October) on the same fruit on which scab severity was estimated. Fruit weight included the shuck. All experiments were factorial in design. The experiment at the Weston location (cv. Pawnee) was a completely randomized experiment with six replicate trees for each treatment described above. In 2015, due to a change in orchard management, eight trees hedge-pruned on one side only were arbitrarily selected from those that had not previously been hedge-pruned. The experiment at the Marshallville location (cv. Desirable) was a randomized complete block design with four blocks and one tree of each treatment sampled per block. The experiment at the Ray City location comprised three contiguous rows of trees, each receiving a different treatment, and three replicate trees were sampled from each treatment.

Weather data. For each location, rainfall data for the growing season from 15 April to 30 September was obtained from the Georgia Automated Environmental Monitoring Network (http://weather. uga.edu/m/index.php). The weather station for the Marshallville location was located in Fort Valley $\left(5.22 \mathrm{~km}\right.$ from the orchard, at $32^{\circ} 31^{\prime}$ $50.5^{\prime \prime} \mathrm{N}, 83^{\circ} 53^{\prime} 24.9^{\prime \prime} \mathrm{W}$ ), for the Weston location it was located in Dawson ( $27.9 \mathrm{~km}$ from the orchard, at $\left.31^{\circ} 45^{\prime} 29.7^{\prime \prime} \mathrm{N}, 84^{\circ} 26^{\prime} 09.0^{\prime \prime} \mathrm{W}\right)$, and for the Ray City location it was located in Alapaha (35.4 km from the orchard, at $31^{\circ} 20^{\prime} 41.0^{\prime \prime} \mathrm{N}, 83^{\circ} 14^{\prime} 26.6^{\prime \prime} \mathrm{W}$ ).

Data analysis. All analyses were performed using SAS V9.4 (SAS Institute, Cary, NC). An assessment of residual versus predicted, normal plots (Q-Q and P-P) and line plots of the residuals showed the data were normal, or approximated to normal, and variances were homogeneous. Data from each experiment were analyzed using a general linear model with main effects of tree treatment, tree side, and sample height (and main effect of block for the experiment in Marshallville), and all interactions of these main effects. For the Weston experiment in 2015, there were main effects only of tree side (hedge-pruned or not) and height. In addition, a means separation was performed on the main effects and interactions based on $t$ tests (LSD) $(\alpha=0.05)$. Analyses of simple main effects of interactions (slices) were also explored.
Linear regression analysis was used to explore the relationship between disease severity on mature fruit and mature fruit weight at each height stratum in each of the experiments. Standard errors of the intercept and slope were calculated. The coefficient of determination $\left(\mathrm{R}^{2}\right)$ was calculated to determine how much of the reduction in fruit weight was accounted for by severity of scab.

\section{Results}

Weather data. The weather experienced in each year was similar at each orchard location (Supplementary Fig. S1). There was higher rainfall and more rainy days at all three locations in 2013 (672.8 to $887.0 \mathrm{~mm}$ ) compared with 2014 (489.0 to $534.2 \mathrm{~mm}$ ) and 2015 (494.0 to $670.1 \mathrm{~mm}$ ), although rainfall in all three years was conducive to moderate to severe scab epidemics. Indeed, 2013 was a particularly favorable year for pecan scab in the Southeast.

Effects on disease severity. The results of the ANOVA of factors that affected scab severity on leaflets, immature, and mature fruit showed that the main effect of hedge-pruning treatment on scab severity in the tree canopy was significant some of the time $(\mathrm{F}=5.8$ to $25.6, P=0.003$ to $<0.0001$ ) (Table 4). Treatment had a significant effect on scab severity on infected leaflets in two out of eight experiments, on immature fruit in one out of eight experiments, and on mature fruit in five out of nine experiments. However, when the mean differences were inspected, they were only a few percent, and among experiments, hedge-pruned trees did not consistently have more severe scab in the canopy when compared with the control trees. Indeed, at the Ray City location, the hedge-pruned trees most often had the least severe scab. In 2015 at the Weston location, there was little difference in scab severity between the pruned and nonpruned sides of the trees. Furthermore, in years immediately after pruning when the growth was most vigorous and susceptible to infection, scab was not any more severe in pruned trees than non-pruned trees (Table 4). Scab severity was lowest on leaflets early in the season and increased on immature fruit and was most severe on mature fruit in all years and locations. Depending on year, experiment, and assessment, pruning treatment resulted in a -9.95 to $+14.63 \%$ difference in scab severity compared with the control.

Height had a significant effect on scab severity on infected leaves, immature, and mature fruit in all of the experiments $(\mathrm{F}=4.4$ to $1,007.1, P=0.01$ to $<0.0001$, respectively, Table 5). In the Weston orchard, scab was consistently most severe on leaflets, immature, and mature fruit highest in the canopy; severity was between 0.42 and $57.94 \%$ more severe compared with the lowest sample height, depending on year and sample time. Generally, later in the season, differences were much greater on fruit, due to more severe scab higher in the canopy. Similarly at the Marshallville location, scab severity was 0.20 to $44.32 \%$ more severe scab at the highest sample point in the canopy compared with the lowest sample point. Three aerial applications were made at this location in all years. At the Ray City orchard, there was a 0.05 to $73.77 \%$ more severe scab at the highest sample point in the canopy compared with the lowest sample point. Aerial applications were made only in 2013 (on mature fruit in 2013 the difference in severity was $73.77 \%$, but in 2014 and 2015 it was 21.10 and $14.76 \%$, respectively).

Table 3. The sample dates to assess scab severity on leaflets and fruit in each experiment in three different orchards in Weston, Marshallville, and Ray City, GA, 2012 to 2015

\begin{tabular}{|c|c|c|c|c|}
\hline \multirow[b]{2}{*}{ Experiment } & \multirow[b]{2}{*}{ Assessment ${ }^{\mathbf{y}}$} & \multicolumn{3}{|c|}{ Year } \\
\hline & & 2013 & 2014 & 2015 \\
\hline \multirow[t]{2}{*}{ Weston cv. Pawnee } & Early assessment & $\ldots{ }^{z}$ & 22 July & 23 July \\
\hline & Late assessment & 29 August & 16 September & 9 September \\
\hline \multirow[t]{2}{*}{ Marshallville cv. Desirable } & Early assessment & 8 August & 11 July & 29 July \\
\hline & Late assessment & 10 October & 25 August & 25 August \\
\hline \multirow[t]{2}{*}{ Ray City cv. Desirable } & Early assessment & 25 June & 16 July & 25 June \\
\hline & Late assessment & 26 September & 3 September & 17 September \\
\hline
\end{tabular}

${ }^{y}$ An early and late assessment was performed in each orchard in each year. The timing varied by a few weeks depending on year and experiment. Fruit weights were recorded for fruit from the late assessment.

${ }^{\mathrm{z}}$ No sample collected. 
Tree side had little effect on the severity of scab on leaflets, immature and mature fruit (Supplementary Tables S3 and S4), being significant on infected leaflets in $14 \%$ of experiments, on immature fruit in $14 \%$ of experiments, and on mature fruit in $38 \%$ of the experiments (as the effect was relatively rare and apparently unrelated to hedge-pruning, data not shown).

In Marshallville, the Block factor was significant as a main effect. Interactions of the main effects were generally inconsistent and bore no clear relationship to hedging treatments in the prior year(s). Furthermore, except where height was the interacting factor, differences among interacting treatments tended to be a few percent or less (data not shown). These data were explored using both means separation and by simple main effect tests (slices) (data not shown).
Effects of hedge-pruning on fruit weight. Treatment influenced fruit weight in six of nine experiments, but there was no consistent effect of hedge-pruning on fruit weight (Table 6). In the Weston orchard, different hedging treatments in 2013 and 2014 might or might not have slightly heavier fruit when compared with the control. In 2015 , the fruit on the hedged side of the trees were actually heavier on average. However, in the Marshallville orchard, there was no difference in fruit weight between treatments in 2013 or 2014, but in 2015, fruit in the hedged trees weighed slightly less. In the Ray City orchard, fruit weighed more in 2013 and 2014 on those trees receiving hedge-pruning, but in 2015, trees in all treatments had fruit that were the same weight. Over all studies, mean fruit weight differed from the control on hedge-pruned trees by a -2.82 to $+5.29 \mathrm{~g}$ difference in mean weight, depending on treatment.

Table 4. The effect of mechanical hedge-pruning treatment on the mean severity of scab on infected leaflets, immature and mature fruit in canopies of pecan trees in experiments in three consecutive years in three pecan orchards in Weston, Marshallville, and Ray City, GA, respectively. Within each year, location and plant part means followed by different letters are significantly different based on $t$ tests (LSD) $(\alpha=0.05)$

\begin{tabular}{|c|c|c|c|c|c|}
\hline \multirow[b]{2}{*}{ Plant part/assessment } & \multirow{2}{*}{$\begin{array}{l}\text { Experiment location } \\
\text { and cultivar }\end{array}$} & \multirow[b]{2}{*}{ Treatment $^{\mathrm{x}}$} & \multicolumn{3}{|c|}{ Year $^{\mathbf{y}}$} \\
\hline & & & 2013 & 2014 & 2015 \\
\hline \multirow{13}{*}{$\begin{array}{l}\text { Leaflets (severity per } \\
\text { infected leaf, \%) }\end{array}$} & \multirow[t]{6}{*}{ Weston cv. Pawnee } & Control & - & $2.1 \mathrm{bc}$ & $0.5 \mathrm{a}$ \\
\hline & & DH2_Y_T & & $\mathbf{h}_{2.5 \mathrm{a}}$ & \\
\hline & & $\mathrm{H} 1 \_\mathrm{Y}$ & & $\mathbf{h}_{2.3 \mathrm{ab}}$ & $\mathbf{h}_{0.7 \mathrm{~b}}$ \\
\hline & & ON_DH2_Y_T & & $1.8 \mathrm{c}$ & \\
\hline & & ON_GH2_T2_Y & & $\mathbf{h}_{2.2 \mathrm{~b}}$ & \\
\hline & & $F$-value $(P)^{\mathrm{z}}$ & & $6.6(<0.0001)$ & $2.2(0.1)$ \\
\hline & \multirow[t]{3}{*}{ Marshallville cv. Desirable } & Control & $1.0 \mathrm{a}$ & $0.5 \mathrm{a}$ & $1.5 \mathrm{a}$ \\
\hline & & Hedged & $\mathbf{h}_{0.9}$ a & $\mathbf{h}_{0.6} \mathrm{a}$ & $1.8 \mathrm{a}$ \\
\hline & & $F$-value $(P)$ & $0.4(0.6)$ & $0.7(0.4)$ & $1.6(0.2)$ \\
\hline & \multirow[t]{4}{*}{ Ray City cv. Desirable } & Control & $0.63 \mathrm{a}$ & $0.10 \mathrm{a}$ & $0.017 \mathrm{a}$ \\
\hline & & Hedge 1S & $\mathbf{h}_{0.76}$ a & $0.06 \mathrm{~b}$ & $0.003 \mathrm{~b}$ \\
\hline & & Hedge $2 \mathrm{~S}$ & $\mathbf{h}_{0.33 \mathrm{~b}}$ & $\mathbf{h}_{0.06 \mathrm{~b}}$ & $0.010 \mathrm{a}$ \\
\hline & & $F$-value $(P)$ & $10(<0.0001)$ & $0.6(0.5)$ & $2.1(0.1)$ \\
\hline \multirow{13}{*}{$\begin{array}{l}\text { Immature fruit } \\
\text { (severity per fruit, \%) }\end{array}$} & \multirow[t]{6}{*}{ Weston cv. Pawnee } & Control & - & $19.5 \mathrm{c}$ & $8.3 \mathrm{a}$ \\
\hline & & DH2_Y_T & & $\mathbf{h}_{20.5 \mathrm{a}}$ & \\
\hline & & $\mathrm{H} 1 \_\overline{\mathrm{Y}}-$ & & $\mathbf{h}_{15.7 \mathrm{bc}}$ & h7.4 a \\
\hline & & ON_DH2_Y_T & & $17.9 \mathrm{bc}$ & \\
\hline & & ON_GH2_T2_Y & & h20.3 b & \\
\hline & & $F$-value $(P)$ & & $7.2(<0.0001)$ & $0.5(0.5)$ \\
\hline & \multirow[t]{3}{*}{ Marshallville cv. Desirable } & Control & $5.8 \mathrm{a}$ & $1.0 \mathrm{a}$ & $1.9 \mathrm{a}$ \\
\hline & & Hedged & h7.5 a & $\mathrm{h}_{1.1 \mathrm{a}}$ & $2.6 \mathrm{a}$ \\
\hline & & $F$-value $(P)$ & $2.1(0.2)$ & $0.5(0.5)$ & $2.8(0.1)$ \\
\hline & \multirow[t]{4}{*}{ Ray City cv. Desirable } & Control & $4.4 \mathrm{a}$ & $0.15 \mathrm{a}$ & $0.08 \mathrm{a}$ \\
\hline & & Hedge $1 \mathrm{~S}$ & h3.8 ab & $0.03 \mathrm{~b}$ & $0.07 \mathrm{a}$ \\
\hline & & Hedge $2 \mathrm{~S}$ & $\mathbf{h}_{3.0 \mathrm{~b}}$ & $\mathbf{h}_{0.03 \mathrm{~b}}$ & $0.04 \mathrm{a}$ \\
\hline & & $F$-value $(P)$ & $2.4(0.09)$ & $0(0.97)$ & $0.4(0.7)$ \\
\hline \multirow{13}{*}{$\begin{array}{l}\text { Mature fruit } \\
\text { (severity per fruit, \%) }\end{array}$} & \multirow[t]{6}{*}{ Weston cv. Pawnee } & Control & $50.8 \mathrm{~b}$ & $37.4 \mathrm{c}$ & $27.8 \mathrm{a}$ \\
\hline & & DH2_Y_T & $\mathbf{h}_{48.3 \mathrm{bc}}$ & $\mathbf{h}_{52.0 \mathrm{a}}$ & \\
\hline & & $\mathrm{H} 1 \_\mathrm{Y}$ & $\mathbf{h}_{51.5 \mathrm{~b}}$ & h $40.3 \mathrm{bc}$ & $\mathbf{h}_{25.6 \mathrm{a}}$ \\
\hline & & ON_DH2_Y_T & h $45.4 \mathrm{c}$ & $40.0 \mathrm{bc}$ & \\
\hline & & ON_GH2_T2_Y & h63.6 a & $\mathbf{h}_{41.2 \mathrm{~b}}$ & \\
\hline & & $F$-value $(P)$ & $21.8(<0.0001)$ & $23.7(<0.0001)$ & $0.5(0.5)$ \\
\hline & \multirow[t]{3}{*}{ Marshallville cv. Desirable } & Control & $38.5 \mathrm{~b}$ & $5.9 \mathrm{a}$ & $2.6 \mathrm{~b}$ \\
\hline & & Hedged & $\mathbf{h}_{44.2 \mathrm{a}}$ & $\mathbf{h}_{6.3 \mathrm{a}}$ & $5.4 \mathrm{a}$ \\
\hline & & $F$-value $(P)$ & $8(0.005)$ & $0.4(0.5)$ & $25.6(<0.0001)$ \\
\hline & \multirow[t]{4}{*}{ Ray City cv. Desirable } & Control & $40.8 \mathrm{a}$ & $6.0 \mathrm{a}$ & $5.31 \mathrm{a}$ \\
\hline & & Hedge $1 \mathrm{~S}$ & $\mathbf{h}_{31.3 \mathrm{~b}}$ & $0.8 \mathrm{~b}$ & $0.08 \mathrm{~b}$ \\
\hline & & Hedge $2 \mathrm{~S}$ & h30.9 b & $\mathbf{h}_{0.6 \mathrm{~b}}$ & $0.03 \mathrm{~b}$ \\
\hline & & $F$-value $(P)$ & $5.8(0.003)$ & $0.1(0.9)$ & $2.7(0.07)$ \\
\hline
\end{tabular}

${ }^{\mathrm{x}}$ In the different experiments the treatments were as follows: Weston: control (no hedging); DH2_Y_T (dormant season hedged on two sides, following year hedged on the opposite two sides [cuts 12 feet from trunk]. Cut tops on hedged sides when height exceeds row width. Repeat the pattern over 2-year periods); H1_Y (hedge one side of the tree each year. Also cut tops on hedged sides when height exceeds row width); ON_DH2_Y_T (repeat 2, except only on expected "on year"); ON_GH2_T2_Y (hedge two sides July during "on year". Opposite two sides next "on year" and every year hedge tops May and July). Management in the Weston orchard changed in 2015, and all trees were hedge-pruned on one side, either the east or west row-side. Thus, in 2015, there was a comparison of hedged and non-hedged sides of trees only. Marshallville: control (no hedging); hedged (one side hedged in year 1, second side year 2 with the cycle repeated on a 3-year basis). Ray City: control (no hedging); hedge 1S (one side hedged in year 1, the second side in year 2 with the cycle occurring only once); hedge $2 \mathrm{~S}$ (both sides hedged in year 1 , with the cycle occurring only once).

${ }^{\mathrm{y}}$ A superscript ' $\mathrm{h}$ ' before the mean severity indicates that those trees received hedge-pruning the previous winter or spring.

${ }^{\mathrm{z}} F$ - and $P$-values indicates the probability that the $F$-value for the treatment effect for the null hypothesis is not significant. 
Fruit collected from different heights had different weights in all experiments (Table 7). Fruit most often weighed less when collected from greater sample heights in the canopy, although in a few experiments the relationship was the reverse, inconsistent, or there was little difference among heights. On only one occasion was fruit mean weight less in the low canopy when compared with that at the highest sample point in the canopy (Weston orchard in 2013). Over all experiments, the difference in mean fruit weight between the highest and lowest sample height ranged from -15.66 to $+2.06 \mathrm{~g}$.

As with the results for the scab severity data, fruit weight was affected by most factors and interactions in at least some experiments and/or assessments ( $\mathrm{F}=2.1$ to $135.2, P=0.05$ to $<0.00001)$ (Supplementary Table S5). Effects of tree side, and the interactions of the main effects on fruit weight were inconsistent and bore no consistent relationship to hedging treatments in the prior year(s). Furthermore, except where height was the interacting factor, differences among interacting treatments were minor (data not shown).

Relationship between sample height, disease severity, and fruit weight. There was no relationship in any experiment between fruit weight and scab severity at the lowest sample height $(5 \mathrm{~m})$ (Table 8$)$. At the second sample height $(18 \mathrm{~m})$, there was a significant relationship between fruit weight and scab severity in some of the experiments $\left(\mathrm{R}^{2}=0.30\right.$ to $0.54, P=0.0003$ to $\left.<0.0001\right)$. Similarly, at the third sample height ( 11 or $12 \mathrm{~m}$, depending on experiment), there was a relationship between fruit weight and scab severity in some of the experiments $\left(\mathrm{R}^{2}=0.21\right.$ to $0.57, P=0.0007$ to $\left.<0.0001\right)$, and at the Ray City orchard, there was a consistent relationship between fruit weight and scab severity at the fourth sample height $\left(17 \mathrm{~m}, \mathrm{R}^{2}=\right.$ 0.52 to $0.67, P<0.0001$ )

\section{Discussion}

The results demonstrate that under typical commercial fungicide programs in the southeastern United States, hedge-pruning of pecan trees does not lead to significantly more disease developing in the tree canopy. Indeed, in the taller trees $(14+\mathrm{m})$ at the Ray City location, that were pruned to $\sim 12 \mathrm{~m}$, the overall effect was to reduce the severity of scab in the canopy. Thus, there is no evidence that hedgepruning results in more severe scab in the year immediately following hedging, or subsequent years. Furthermore, there was little evidence of a treatment $x$ tree side interaction, further demonstrating that there was no detectable effect of hedging on scab severity. These results are in agreement with prior observations (Stevenson 2013). However, this observation is based on the premise that appropriate fungicides are applied at appropriate intervals to minimize the risk of infection. It is unlikely that commercial pecan growers in the Southeast would not apply fungicides to a susceptible cultivar, whether it has been hedge-pruned or not. It would be valuable to explore the incidence and severity of scab and epidemic development in

Table 5. The effect of sample height in a pecan tree canopy on the mean severity of scab on infected leaflets, immature and mature fruit in experiments in three consecutive years in three orchards in Weston, Marshallville, and Ray City, GA, respectively. Within each year, location and plant part means followed by different letters are significantly different based on $t$ tests (LSD) $(\alpha=0.05)$

\begin{tabular}{|c|c|c|c|c|c|}
\hline \multirow[b]{2}{*}{ Plant part/assessment } & \multirow{2}{*}{$\begin{array}{l}\text { Experiment location } \\
\text { and cultivar }\end{array}$} & \multirow{2}{*}{$\begin{array}{c}\text { Sample } \\
\text { height (m) }\end{array}$} & \multicolumn{3}{|c|}{ Year } \\
\hline & & & 2013 & 2014 & 2015 \\
\hline \multirow{13}{*}{$\begin{array}{l}\text { Leaflets (severity per } \\
\text { infected leaf, \%) }\end{array}$} & \multirow[t]{4}{*}{ Weston cv. Pawnee } & 5 & \multirow[t]{4}{*}{-} & $2.0 \mathrm{~b}$ & $0.4 \mathrm{~b}$ \\
\hline & & 8 & & $2.2 \mathrm{ab}$ & $0.7 \mathrm{a}$ \\
\hline & & 11 & & $2.4 \mathrm{a}$ & $0.8 \mathrm{a}$ \\
\hline & & $F$-value $(P)$ & & $38.9(<0.0001)$ & $6(0.003)$ \\
\hline & \multirow[t]{4}{*}{ Marshallville cv. Desirable } & 5 & $0.5 \mathrm{~b}$ & $0.5 \mathrm{~b}$ & $1.1 \mathrm{~b}$ \\
\hline & & 8 & $1.0 \mathrm{a}$ & $0.6 \mathrm{a}$ & $2.0 \mathrm{a}$ \\
\hline & & 11 & $1.3 \mathrm{a}$ & $0.7 \mathrm{a}$ & $1.9 \mathrm{a}$ \\
\hline & & $F$-value $(P)$ & $7.3(0.0007)$ & $11.1(<0.0001)$ & $4.4(0.01)$ \\
\hline & \multirow[t]{5}{*}{ Ray City cv. Desirable } & 5 & $0.3 \mathrm{~b}$ & $0.02 \mathrm{c}$ & $0.002 \mathrm{c}$ \\
\hline & & 8 & $0.5 \mathrm{~b}$ & $0.05 \mathrm{c}$ & $0.004 \mathrm{bc}$ \\
\hline & & 12 & $0.9 \mathrm{a}$ & $0.09 \mathrm{~b}$ & $0.011 \mathrm{~b}$ \\
\hline & & 17 & - & $0.28 \mathrm{a}$ & $0.053 \mathrm{a}$ \\
\hline & & $F$-value $(P)$ & $15.2(<0.0001)$ & $65.4(<0.0001)$ & $28.8(<0.0001)$ \\
\hline \multirow{13}{*}{$\begin{array}{l}\text { Immature fruit } \\
\text { (severity per fruit, \%) }\end{array}$} & \multirow[t]{4}{*}{ Weston cv. Pawnee } & 5 & - & $7.2 \mathrm{c}$ & $1.0 \mathrm{c}$ \\
\hline & & 8 & & $14.1 \mathrm{~b}$ & $3.5 \mathrm{~b}$ \\
\hline & & 11 & & $34.5 \mathrm{a}$ & $18.8 \mathrm{a}$ \\
\hline & & $F$-value $(P)$ & & $620.5(<0.0001)$ & $138(<0.0001)$ \\
\hline & \multirow[t]{4}{*}{ Marshallville cv. Desirable } & 5 & $4.0 \mathrm{~b}$ & $0.7 \mathrm{~b}$ & $0.4 \mathrm{~b}$ \\
\hline & & 8 & $5.4 \mathrm{~b}$ & $1.0 \mathrm{ab}$ & $1.2 \mathrm{~b}$ \\
\hline & & 11 & $10.7 \mathrm{a}$ & $1.5 \mathrm{a}$ & $5.2 \mathrm{a}$ \\
\hline & & $F$-value $(P)$ & $10.9(<0.0001)$ & $5.3(0.006)$ & $57.5(<0.0001)$ \\
\hline & \multirow[t]{5}{*}{ Ray City cv. Desirable } & 5 & $1.0 \mathrm{c}$ & $0.01 \mathrm{~b}$ & $0.03 \mathrm{~b}$ \\
\hline & & 8 & $2.3 \mathrm{~b}$ & $0.02 \mathrm{~b}$ & $0.05 \mathrm{~b}$ \\
\hline & & 12 & $7.9 \mathrm{a}$ & $0.05 \mathrm{~b}$ & $0.08 \mathrm{~b}$ \\
\hline & & 17 & - & $0.55 \mathrm{a}$ & $0.19 \mathrm{a}$ \\
\hline & & $F$-value $(P)$ & $63.5(<0.0001)$ & $27.6(<0.0001)$ & $5.1(0.002)$ \\
\hline \multirow{13}{*}{$\begin{array}{l}\text { Mature fruit } \\
\text { (severity per fruit, \%) }\end{array}$} & \multirow[t]{4}{*}{ Weston cv. Pawnee } & 5 & $25.2 \mathrm{c}$ & $12.9 \mathrm{c}$ & $2.8 \mathrm{c}$ \\
\hline & & 8 & $55.9 \mathrm{~b}$ & $42.3 \mathrm{~b}$ & $24.1 \mathrm{~b}$ \\
\hline & & 11 & $75.0 \mathrm{a}$ & $70.8 \mathrm{a}$ & $51.8 \mathrm{a}$ \\
\hline & & $F$-value $(P)$ & $474.6(<0.0001)$ & $1007.1(<0.0001)$ & $188(<0.0001)$ \\
\hline & \multirow[t]{4}{*}{ Marshallville cv. Desirable } & 5 & $21.0 \mathrm{c}$ & $3.6 \mathrm{c}$ & $1.1 \mathrm{~b}$ \\
\hline & & 8 & $37.6 \mathrm{~b}$ & $6.0 \mathrm{~b}$ & $2.3 \mathrm{~b}$ \\
\hline & & 11 & $65.3 \mathrm{a}$ & $8.7 \mathrm{a}$ & $8.6 \mathrm{a}$ \\
\hline & & $F$-value $(P)$ & $162.4(<0.0001)$ & $16.1(<0.0001)$ & $74.4(<0.0001)$ \\
\hline & \multirow[t]{5}{*}{ Ray City cv. Desirable } & 5 & $3.9 \mathrm{~d}$ & $0.2 \mathrm{~b}$ & $0.9 \mathrm{~b}$ \\
\hline & & 8 & $20.6 \mathrm{c}$ & $0.3 \mathrm{~b}$ & $1.1 \mathrm{~b}$ \\
\hline & & 12 & $58.8 \mathrm{~b}$ & $1.7 \mathrm{~b}$ & $0.5 \mathrm{~b}$ \\
\hline & & 17 & $77.6 \mathrm{a}$ & $21.3 \mathrm{a}$ & $15.6 \mathrm{a}$ \\
\hline & & $F$-value $(P)$ & $410.7(<0.0001)$ & $151.3(<0.0001)$ & $46.2(<0.0001)$ \\
\hline
\end{tabular}


the canopies of hedge-pruned and non-hedge-pruned trees that do not receive any fungicide. This is important to know, because it will provide insight into whether epidemics have the potential to be more severe in a hedge-pruned canopy and reaffirm the need for diligence in fungicide application.

Hedge-pruning was developed to improve tree access and other orchard management practices, and particularly to reduce alternate bearing (Wood and Stahmann 2004). It is common practice in the arid southwestern United States (Heerema et al. 2012), but was not developed with the primary aim of making trees more amenable to control of scab. As a result of a gradient in spray coverage (Bock et al. 2015; Reilly et al. 2007; Sumner 2004), effectiveness of pecan scab control varies with height in a tree (Bertrand and Brenneman 2001; Bock et al. 2013). Not surprisingly, sample height was the single most influential factor on scab severity, and the relationship was profound. Thus, even with an excellent commercial fungicide regime, more severe scab will develop in the upper canopy of tall orchard trees, particularly at heights $>12 \mathrm{~m}$; but even at heights $<12 \mathrm{~m}$, scab may be more severe compared with the base of the canopy.
The reason for a gradient at heights $<12 \mathrm{~m}$ is likely due to increasingly uneven fungicide distribution with distance from the source. Thus, it appears there are at least two alternatives to improve scab management in tall trees. The first is aerial application, which will provide reduction in scab severity in the upper canopy (Bertrand and Brenneman 2001; Reilly et al. 2007). The second is hedgepruning, which ensures the whole canopy volume is within reach of ground-applied fungicide sprays. Use of a volute on air-blast sprayers might also help reduce severity in the upper canopy, but this has not been demonstrated. The area cultivated under scab-susceptible cultivars in the southeastern United States is substantial, and they are dominant cultivars in recent plantings (Wells 2014). Thus, management of scab in the tree canopy at heights $>12 \mathrm{~m}$ will remain an issue for many decades.

Despite two aerial applications of fungicide to the experiment at the Ray City location in 2013, severity on mature fruit was $>55 \%$ at heights $\geq 12 \mathrm{~m}$. In 2014 and 2015 , no aerial applications were applied, and although disease was well-controlled at $\leq 12 \mathrm{~m}$, there was severe disease at $17 \mathrm{~m}$. At the Marshallville location, three aerial

Table 6. The effect of mechanical hedge-pruning treatment in a pecan tree canopy on the mean mature fruit weight (g) in experiments in three consecutive years in pecan orchards in Weston, Marshallville, and Ray City, GA, respectively. Within each year and location, means followed by different letters are significantly different based on $t$ tests (LSD) $(\alpha=0.05)$

\begin{tabular}{|c|c|c|c|c|}
\hline \multirow[b]{2}{*}{ Experiment location and cultivar } & \multirow[b]{2}{*}{ Treatment $^{\mathrm{x}}$} & \multicolumn{3}{|c|}{ Year $^{y}$} \\
\hline & & 2013 & 2014 & 2015 \\
\hline \multirow[t]{6}{*}{ Weston cv. Pawnee } & Control & $22.4 \mathrm{c}$ & $22.8 \mathrm{~b}$ & $32.7 \mathrm{~b}$ \\
\hline & DH2_Y_T & h $24.2 \mathrm{~b}$ & $\mathbf{h}_{20.4 \mathrm{c}}$ & \\
\hline & H1_Y & h22.4 c & h23.1 b & h35.1 a \\
\hline & ON_DH2_Y_T & $\mathbf{h}_{25.7 \mathrm{a}}$ & $22.5 \mathrm{~b}$ & \\
\hline & ON_GH2_T2_Y & h22.5 c & h25.4 a & \\
\hline & $F$-value $(P)^{\mathrm{z}}$ & $14.8(<0.0001)$ & $24.2(<0.0001)$ & $0.5(0.5)$ \\
\hline \multirow[t]{3}{*}{ Marshallville cv. Desirable } & Control & $32.4 \mathrm{a}$ & $21.3 \mathrm{a}$ & $27.8 \mathrm{a}$ \\
\hline & Hedged & h31.6 a & h21.4 a & $25.0 \mathrm{~b}$ \\
\hline & $F$-value $(P)$ & $1.6(0.2)$ & $0.2(0.6)$ & $90.7(<0.0001)$ \\
\hline \multirow[t]{4}{*}{ Ray City cv. Desirable } & Control & $31.8 \mathrm{~b}$ & $27.6 \mathrm{~b}$ & $41.3 \mathrm{a}$ \\
\hline & Hedge $1 \mathrm{~S}$ & h37.0 a & $28.7 \mathrm{a}$ & $40.4 \mathrm{a}$ \\
\hline & Hedge $2 \mathrm{~S}$ & h36.2 a & h28.7 a & $41.3 \mathrm{a}$ \\
\hline & $F$-value $(P)$ & $16.5(<0.0001)$ & $4.2(0.02)$ & $3.5(0.03)$ \\
\hline
\end{tabular}

${ }^{\mathrm{x}}$ In the different experiments the treatments were as follows: Weston: control (no hedging); DH2_Y_T (dormant season hedged on two sides, following year hedged on the opposite two sides [cuts 12 feet from trunk]. Cut tops on hedged sides when height exceeds row width. Repeat the pattern over 2-year periods); H1_Y (hedge one side of the tree each year. Also cut tops on hedged sides when height exceeds row width); ON_DH2_Y_T (repeat 2, except only on expected "on year"); ON_GH2_T2_Y (hedge 2 sides July during "on year". Opposite two sides next "on year" and every year hedge tops May and July). Management in the Weston orchard changed in 2015, and all trees were hedge-pruned on one side, either the east or west row-side. Thus, in 2015, there was a comparison of hedged and non-hedged sides of trees only. Marshallville: control (no hedging); hedged (One side hedged in year 1, second side year 2 with the cycle repeated on a 3-year basis). Ray City: control (no hedging); hedge 1S (one side hedged in year 1, the second side in year 2 with the cycle occurring only once); hedge $2 \mathrm{~S}$ (both sides hedged in year 1 , with the cycle occurring only once).

${ }^{y}$ A superscript ' ${ }^{\prime}$ ' before the mean severity indicates that those trees received hedge-pruning the previous winter or spring.

${ }^{\mathrm{z}} F$ - and $P$-values indicates the probability that the $F$-value for the treatment effect for the null hypothesis is not significant.

Table 7. The effect of sample height in pecan tree canopies on the mean mature fruit weight $(\mathrm{g})$ in experiments studying effects of mechanical hedge-pruning in three consecutive years in pecan orchards in Weston, Marshallville and Ray City, GA, respectively. Within each year and location means followed by different letters are significantly different based on $t$ tests (LSD) $(\alpha=0.05)$

\begin{tabular}{|c|c|c|c|c|}
\hline \multirow{2}{*}{$\begin{array}{l}\text { Experiment location } \\
\text { and cultivar }\end{array}$} & \multirow{2}{*}{$\begin{array}{c}\text { Sample } \\
\text { height (m) }\end{array}$} & \multicolumn{3}{|c|}{ Year } \\
\hline & & 2013 & 2014 & 2015 \\
\hline \multirow[t]{4}{*}{ Weston cv. Pawnee } & 5 & $22.6 \mathrm{~b}$ & $24.1 \mathrm{a}$ & $35.4 \mathrm{a}$ \\
\hline & 8 & $22.8 \mathrm{~b}$ & $23.2 \mathrm{~b}$ & $34.2 \mathrm{a}$ \\
\hline & 11 & $24.7 \mathrm{a}$ & $21.2 \mathrm{c}$ & $32.1 \mathrm{~b}$ \\
\hline & $F$-value $(P)$ & $16.4(<0.0001)$ & $28.32(<0.0001)$ & $188(<0.0001)$ \\
\hline \multirow[t]{4}{*}{ Marshallville cv. Desirable } & 5 & $36.0 \mathrm{a}$ & $21.8 \mathrm{a}$ & $25.8 \mathrm{~b}$ \\
\hline & 8 & $33.5 \mathrm{~b}$ & $21.7 \mathrm{a}$ & $27.3 \mathrm{a}$ \\
\hline & 11 & $26.5 \mathrm{c}$ & $20.6 \mathrm{~b}$ & $25.9 \mathrm{~b}$ \\
\hline & $F$-value $(P)$ & $90.9(<0.0001)$ & $10(<0.0001)$ & $10.9(<0.0001)$ \\
\hline \multirow[t]{5}{*}{ Ray City cv. Desirable } & 5 & $40.7 \mathrm{a}$ & $27.9 \mathrm{~b}$ & $40.6 \mathrm{a}$ \\
\hline & 8 & $38.2 \mathrm{~b}$ & $28.9 \mathrm{a}$ & $42.0 \mathrm{a}$ \\
\hline & 12 & $30.2 \mathrm{c}$ & $28.4 \mathrm{ab}$ & $41.6 \mathrm{a}$ \\
\hline & 17 & $25.1 \mathrm{~d}$ & $26.8 \mathrm{c}$ & $38.8 \mathrm{~b}$ \\
\hline & $F$-value $(P)$ & $135.2(<0.0001)$ & $4.1(0.007)$ & $6.9(0.0002)$ \\
\hline
\end{tabular}


applications were made each season, yet scab was still more severe at $11 \mathrm{~m}$, although the difference between severity at the highest and lowest sample heights was less compared with the other locations, except in 2013. Without appropriate controls, it is not possible to ascertain whether the lower severity at the Marshallville location was due to the timing and frequency of the aerial applications, or characteristics of the location being less conducive to scab (Sparks et al. 2009). The 2013 season was particularly wet, so it is not surprising that scab was most severe at all locations.

Hedge-pruning did not reduce fruit weight. However, smaller canopies of hedge-pruned trees reduces yield per tree, so trees in hedgepruned systems should be planted at a higher density to maintain yield per unit area (Wood 2009; Wood and Stahmann 2004). Sample height did affect fruit weight, with fruit weight in most cases reduced at the highest sample points where there was more severe scab, compared with lower in the canopy. The relationship between fruit weight and severity of scab on fruit demonstrates that the disease can have profound effects on the fruit at greater heights in the canopy. Yield impacts of scab have been demonstrated (Goff and Miller 1978; Gottwald and Bertrand 1982, 1983; Sanderlin 1995; Stevenson and Bertrand 2001), and the results we present confirm the effect of increasing scab severity in reducing fruit weight. Although we did not address other components of yield that are affected by scab (for example, kernel quality or fruit drop), these too are likely impacted in years with above-average rainfall or if disease develops in the upper canopy (such as occurred in 2013, and to a lesser extent in 2014 and 2015). In 2013, fruit drop was observed from the upper canopy of tall trees due to severe scab (Bock, personal observation).
Seven to 10 sprays of fungicide are typically applied in an average season to control scab (Brenneman et al. 1999), but as seen in this study, 20+ might sometimes be applied. Systemic fungicides might offer some advantages where distribution is patchy (Brown 2015), although this could lead to dosage issues and thus fungicide resistance. When applied aerially, systemic fungicides are almost certainly the best option due to their propensity for some redistribution. Phosphites, recently recommended for use on pecan (Bock et al. 2012), may be particularly systemic, but residue issues in the kernels may preclude extensive use of the chemistry (Anon. 2014).

The scab lesions at heights $>12 \mathrm{~m}$ are a source of inoculum for the canopy below. Scab is demonstrated to be both splash and wind dispersed (Gottwald and Bertrand 1982), but the relative contribution of allo- and auto-infection in a canopy remains unquantified. The results of this study and others (Bertrand and Brenneman 2001; Bock et al. 2013) indicate that a source of inoculum in the upper canopy of commercially grown orchard trees that are taller than $\sim 12 \mathrm{~m}$ is likely commonplace, and might contribute to explosive buildup of disease when conditions are favorable for epidemic development.

An alternative to reduce disease could be selective limb removal (Lombardini 2006; Worley 1985; Worley et al. 1996), and this method of pruning has been shown to reduce severity of apple scab (Holb 2005), most likely by making the microclimate less conducive to disease, removing inoculum sources, and improving fungicide penetration (Travis et al. 1987). However, pecan trees are taller than apple trees, and although selective pruning might help reduce severity of pecan scab, much of the canopy of tall trees will remain beyond the reach of efficacious fungicide spray coverage, making

Table 8. Regression analysis ${ }^{\mathrm{u}}$ of mature pecan fruit weight and severity of scab on those fruit at different heights in three different experiments in Weston, Marshallville, and Ray City, GA

\begin{tabular}{|c|c|c|c|c|c|c|c|}
\hline \multirow{2}{*}{$\begin{array}{l}\text { Experiment location } \\
\text { and cultivar }\end{array}$} & \multirow[b]{2}{*}{ Year } & \multirow[b]{2}{*}{ Height (m) } & \multicolumn{5}{|c|}{ Regression parameters } \\
\hline & & & $F(P)^{\mathbf{v}}$ & $a^{w}$ & $\mathbf{b}^{\mathbf{x}}$ & $R^{2 y}$ & $\overline{C^{2}}$ \\
\hline \multirow[t]{9}{*}{ Weston cv. Pawnee } & 2013 & 5 & $15.3(0.0001)$ & $23.8(0.42)$ & $-0.05(0.01)$ & 0.03 & 27 \\
\hline & & 8 & $19.2(<0.0001)$ & $27.1(1.02)$ & $-0.07(0.02)$ & 0.04 & 46 \\
\hline & & 11 & $129.5(<0.0001)$ & $34.0(0.86)$ & $-0.12(0.01)$ & 0.21 & 24 \\
\hline & 2014 & 5 & $14(0.0002)$ & $25.3(0.46)$ & $-0.09(0.02)$ & 0.03 & 31 \\
\hline & & 8 & $3(0.07)$ & $24.0(0.50)$ & $-0.02(0.01)$ & 0.01 & 25 \\
\hline & & 11 & $70(<0.0001)$ & $27.8(0.82)$ & $-0.09(0.01)$ & 0.12 & 26 \\
\hline & 2015 & 5 & $1.8(0.2)$ & $36.0(0.79)$ & $-0.18(0.14)$ & 0.01 & 24 \\
\hline & & 8 & $11.6(0.0008)$ & $36.1(0.82)$ & $-0.08(0.02)$ & 0.07 & 22 \\
\hline & & 11 & $12.5(0.0005)$ & $35.7(1.14)$ & $-0.07(0.02)$ & 0.07 & 22 \\
\hline \multirow[t]{9}{*}{ Marshallville cv. Desirable } & 2013 & 5 & $34.6(<0.0001)$ & $38.4(0.56)$ & $-0.11(0.02)$ & 0.18 & 14 \\
\hline & & 8 & $185.2(<0.0001)$ & $39.7(0.59)$ & $-0.17(0.01)$ & 0.54 & 14 \\
\hline & & 11 & $212.9(<0.0001)$ & $40.2(1.04)$ & $-0.21(0.01)$ & 0.57 & 21 \\
\hline & 2014 & 5 & $18.4(<0.0001)$ & $22.4(0.27)$ & $-0.16(0.04)$ & 0.10 & 14 \\
\hline & & 8 & $67.4(<0.0001)$ & $23.1(0.28)$ & $-0.22(0.03)$ & 0.30 & 13 \\
\hline & & 11 & $42.0(<0.0001)$ & $21.6(0.30)$ & $-0.12(0.02)$ & 0.21 & 15 \\
\hline & 2015 & 5 & $3.7(0.06)$ & $26.4(0.43)$ & $-0.56(0.29)$ & 0.02 & 13 \\
\hline & & 8 & $28.8(<0.0001)$ & $28.6(0.39)$ & $-0.54(0.10)$ & 0.15 & 14 \\
\hline & & 11 & $126.6(<0.0001)$ & $28.8(0.42)$ & $-0.33(0.03)$ & 0.45 & 17 \\
\hline \multirow[t]{12}{*}{ Ray City cv. Desirable } & 2013 & 5 & $16.9(<0.0001)$ & $41.7(0.42)$ & $-0.24(0.06)$ & 0.09 & 12 \\
\hline & & 8 & $121.8(<0.0001)$ & $42.3(0.57)$ & $-0.20(0.02)$ & 0.41 & 15 \\
\hline & & 12 & $119.5(<0.0001)$ & $42.2(1.19)$ & $-0.20(0.02)$ & 0.40 & 20 \\
\hline & & 17 & $101.3(<0.0001)$ & $51.2(2.67)$ & $-0.34(0.03)$ & 0.54 & 23 \\
\hline & 2014 & 5 & $0.0(1.0)$ & $27.9(0.29)$ & $0.03(0.61)$ & 0.00 & 13 \\
\hline & & 8 & $1.6(0.2)$ & $29.0(0.27)$ & $-0.31(0.24)$ & 0.01 & 12 \\
\hline & & 12 & $11.9(0.0007)$ & $28.7(0.25)$ & $-0.18(0.05)$ & 0.06 & 11 \\
\hline & & 17 & $121.1(<0.0001)$ & $30.6(0.46)$ & $-0.18(0.02)$ & 0.67 & 9 \\
\hline & 2015 & 5 & $3.2(0.1)$ & $40.3(0.52)$ & $0.34(0.19)$ & 0.02 & 14 \\
\hline & & 8 & $13.9(0.0003)$ & $41.5(0.37)$ & $0.40(0.11)$ & 0.09 & 10 \\
\hline & & 12 & $1.6(0.2)$ & $41.4(0.47)$ & $0.45(0.36)$ & 0.01 & 13 \\
\hline & & 17 & $62.0(<0.0001)$ & $42.8(0.87)$ & $-0.26(0.03)$ & 0.52 & 14 \\
\hline
\end{tabular}

\footnotetext{
u Linear regression function, $y=a+b x(a=$ intercept, $b=$ slope).

${ }^{v} F=F$-distribution value that tests goodness of fit for the model. $P=$ Probability the $F$-value is significant.

${ }^{\mathrm{w}} \mathrm{a}=$ intercept (standard error of the intercept).

$\mathrm{x} \mathrm{b}=$ slope (standard error of the slope).

${ }^{\mathrm{y}} \mathrm{R}^{2}=$ coefficient of determination (proportion of variability accounted for by $\mathrm{X}$ ).

${ }^{\mathrm{z}} \mathrm{CV}=$ coefficient of variation of the regression (a unit-less measure of variation in the data).
} 
hedge-pruning a more attractive (and possibly less labor intensive) operation compared with selective limb removal.

The frequency of hedging in relation to scab management in the southeastern United States is not established. Maintaining (or reducing) the height to approximately $12 \mathrm{~m}$ will enable improved control of scab on a greater proportion of fruit. Within 2 to 3 years, shoots might grow several meters above this height, and consequently any fruit on these limbs will no longer be afforded the same protection. Regardless, the longer the hedging cycle, the taller the trees will become, and it will again become increasingly challenging to manage scab. There may be unforeseen latent issues that develop from the hedge-pruning process. Wood rot fungi are ubiquitous in the southeastern United States and have been found colonizing pecan (Farr et al. 1989; McMurran 1918). Wood rot fungi on pruned limbs of older trees of another orchard crop in the Southeast, peach, is a recognized problem (Chen et al. 2015). Pecan orchards are long lived and pruning wounds might create infection courts for rapid colonization by various white and brown rot fungi. Colonization could compromise the integrity of the tree's yield-bearing, scaffold limbs. Limbs can be laden with a heavy yield and are vigorously shaken to release nuts, so if weakened by rot might eventually snap during this process.

We conclude that in the presence of a robust fungicide program, hedge-pruning does not result in more severe scab in canopies of pecan trees, neither in the year immediately after hedging, nor subsequent years. Even with excellent ground applied sprays, scab will develop in the upper canopy (even if a few additional aerial applications are made). Hedge-pruning scab-susceptible pecan trees results in most of the canopy being assured efficacious fungicide spray coverage.

\section{Acknowledgments}

CHB, MWW, and BWW are supported by the USDA-ARS National Programs through CRIS project 6042-21220-012-00. Additional support came from two grants from the Georgia Commodity Commission for Pecans. We appreciate the technical support of Wanda Evans and Shirley Anderson, temporary hire Susan Burrell, and assistance from summer student hires Jason Shipp, Kaylee Carlson, Andrew Hudgens, Frank Wilson, and Sarah Morrill. We thank several growers for their time and discussion, and in particular we appreciate the generosity, time, and support of Mr. Buck Paulk, Mr. Richard Merritt, and Mr. Mike Jaros. We are grateful to Mr. Tom Stevenson for use of images of hedge-pruning in pecan.

\section{Literature Cited}

Anon. 2014. EU changes definition of phosphite residues. December 30, 2014. California Walnuts. https://www.walnuts.org/walnut-industry/announcements/ eu-changes-definition-of-phosphite-residues/

Bertrand, P. F., and Brenneman, T. B. 2001. Aerial and weather based fungicide application for pecan scab control. Proc. Southeast Pecan Grow. Assoc. 94: 62-69.

Bock, C. H., Brenneman, T. B., Hotchkiss, M. W., and Wood, B. W. 2012. Evaluation of a phosphite fungicide to control pecan scab in the southeastern USA. Crop Prot. 36:58-64

Bock, C. H., Cottrell, T. E., Hotchkiss, M. W., and Wood, B. W. 2013. Vertical distribution of scab in large pecan trees. Plant Dis. 97:626-634.

Bock, C. H., Hotchkiss, M. W., Cottrell, T. E., and Wood, B. W. 2015. The effect of sample height on spray coverage in mature pecan trees. Plant Dis. 99: 916-925.

Bock, C. H., Stevenson, K. L., Arias, R. S., and Wood, B. W. 2014. Genetic diversity and population structure of Fusicladium effusum on pecan in the U.S.A. Plant Dis. 98:916-923.

Brenneman, T. B., Bertrand, P. F., and Mullinix, B. 1999. Spray advisories for pecan scab: recent developments in Georgia. Pages 7-14 in: The Pecan Industry: Current Situation and Future Challenges, Third National Pecan Workshop Proceedings. B. E. McCraw, E. H. Dean, and B. W. Wood, eds. USDA Agricultural Research Service 1998-04.

Brock, J., and Brenneman, T. B. 2015. Pecan. Page 14 in: Georgia Plant Disease Loss Estimates 2013, Compiled by A. Martinez-Espinoza, University of Georgia Extension. Annual Publication 102-6. http://extension.uga.edu/ publications/

Brown, K. A. 2015. Evaluation of systemic fungicides and dormant spray applications in pecans and implications for disease management. M. S. Thesis, University of Georgia.

Chen, C., Bock, C. H., Hotchkiss, M. W., Garbelotto, M. M., and Cottrell, T. E. 2015. Observation and identification of wood-decay fungi from the heartwood of peach tree limbs in central Georgia, USA. Eur. J. Plant Pathol. 143:11-23.
Conner, P. J., and Stevenson, K. L. 2004. Pathogenic variation of Cladosporium caryigenum isolates and corresponding differential resistance in pecan. HortSci. 39:553-557.

Converse, R. H. 1960. Physiologic specialization in Fusicladium effusum and its evaluation in vitro. Phytopathology 50:527-531.

Demaree, J. B. 1924. Pecan scab with special reference to sources of the early spring infections. J. Agric. Res. 28:321-333.

Farr, D. F., Bills, G. F., Chamuris, G. P., and Rossman, A. Y. 1989. Fungi on Plants and Plant Products in the United States. APS Press, St. Paul, MN.

Goff, W., and Miller, R. W. 1978. Effectiveness of certain fungicides for the control of pecan diseases. Proceedings of the Southeastern Pecan Growers Association Annual Meeting 71:115-119.

Goff, W. D., McVay, J. R., and Gazaway, W. S. 1996. Page 222 in: Pecan production in the Southeast. Alabama Cooperative Extension System Circular ANR-459. Auburn University, Auburn, AL.

Gottwald, T. R. 1985. Influence of temperature, leaf wetness period, leaf age, and spore concentration on infection of pecan leaves by conidia of Cladosporium caryigenum. Phytopathology 75:190-194.

Gottwald, T. R., and Bertrand, P. F. 1982. Patterns of diurnal and seasonal airborne spore concentrations of Fusicladium effusum and its impact on a pecan scab epidemic. Phytopathology 72:330-335.

Gottwald, T. R., and Bertrand, P. F. 1983. Effect of time of inoculation with Cladosporium caryigenum on pecan scab development and nut quality. Phytopathology 73:714-718.

Heerema, R., Lewis, B., and Fontes, B. 2012. Impact of Hedge Pruning (New Mexico). Proceedings, 46th Annual Western Pecan Growers Association March 4-6, 2012, Hotel Encanto De Las Cruces, Las Cruces, New Mexico. 12-16.

Holb, I. 2005. Effect of pruning apple in organic apple production. Plant Dis. 89 611-618.

Holtz, B., Sibbett, S., Kallsen, C., Hendricks, L., Beede, B., Michailides, T., Teviotdale, B., and Ferguson, L. 2002. Evaluation of pruning and fungicide sprays to control Botryosphaeria blight of Pistacia vera. Acta Hortic.: 569-575.

Littrell, R. H. 1976. Resistant pecan scab strains to benlate and pecan fungicide management. Pecan South 3:335-337.

Lombardini, L. 2006. One-time pruning of pecan trees induced limited and shortterm benefits in canopy light penetration, yield, and nut quality. HortSci. 41: 1469-1473.

Lorano-Gonzalez, R., Storey, B. J., and Harris, M. K. 1992. Three-dimensional characterization of bearing pecan tree. HortSci. 27:1181-1183.

McMurran, M. M. 1918. Preventing wood rot in pecan trees. Farmers Bulletin 995 Bureau of Plant Industry, United States Department of Agriculture, Washington, DC.

Olsen, W. H., Lampinen, B., Metcalf, S., Walton, J., and Miller, S. 2003 Comparisons between mechanical hedging treatments and the non-hedged check - 2003. Walnut Research Reports, University of California, Davis, CA. Online: http://walnutresearch.ucdavis.edu/2003/2003_171.pdf

Olsen, W. H., Osgood, J., Ramos, D., and Roncoroni, E. 1974. High density planting. Walnut Research Reports, University of California, Davis, CA Online: http://walnutresearch.ucdavis.edu/Topic_results.asp?txtSecNo=20

Probst, C., Nelson, M. E., Grove, G. G., Twomey, M. C., and Gent, D. H. 2016. Hop powdery mildew control through alteration of spring pruning practices. Plant Dis. 100:1599-1605.

Reilly, C. C., Wood, B. W., Cottrell, T. E., Sumner, P., Wells, L., and Funderburk, F. 2007. Comparison of ground and aerial application, fungicide deposition and biological activity in large pecan trees. Proc. Southeast Pecan Grow. Assoc. 100:115-122.

Sanderlin, R. S. 1995. Effect of nut scab on pecan yield and quality components. Pages 45-58 in: Sustaining Pecan Productivity into the 21st Century. Proceedings of the Second National Pecan Workshop. M. W. Smith, W. Reid, and B. W. Wood, eds. USDA-ARS. 1995-3.

Shtienberg, D., Zilberstaine, M., Oppenheim, D., Levi, S., Shwartz, H., and Kritzman, G. 2003. New considerations for pruning in management of fire blight in pears. Plant Dis. 87:1083-1088.

Sparks, D. 1992. Pecan Cultivars: The Orchard's Foundation. Pecan Production Innovations, Watkinsville, GA.

Sparks, D., Yates, I. E., Bertrand, P. F., and Brenneman, T. B. 2009. The relative importance of elevation and rainy days on the incidence of scab damage of pecan nuts in the southeastern USA. J. Hortic. Sci. Biotechnol. 84:137-142.

Stevenson, K. L. 1999. Fungicide resistance management in pecans. S. East Pecan Growers Assoc. 92:58-64.

Stevenson, K. L., and Bertrand, P. F. 2001. Within-season dynamics of yield loss due to pecan scab fruit infections. Phytopathology 91:S85.

Stevenson, K. L., Brenneman, T. B., and Brock, J. 2014. Results of the 2014 Pecan Scab Fungicide Sensitivity monitoring program. Georgia Pecan Grower Mag. 26(3):16, 18, 20-23.

Stevenson, T. 2013. Hedging in the Southeast. Georgia Pecan Grower Mag. 24: 28-31.

Stone, D. E. 1997. Carya illinoinensis. In: Flora of North America North of Mexico, Vol. 3. Flora of North America Editorial Committee, eds. Oxford University Press, New York and Oxford. Online: http://www.efloras.org/ florataxon.aspx?flora_id=1\&taxon_id=210000185 
Sumner, P. E. 2004. Experiences with Pecan Air Blast Sprayers. Presented at The 2004 American Society of Agricultural Engineers/Canadian Society of Agricultural Engineers Annual International Meeting, Fairmont Chateau Laurier, The Westin, Government Centre, Ottawa, Ontario, Canada, 1-4 August 2004.

Travis, J. W., Skroch, W. A., and Sutton, T. B. 1987. Effect of canopy density on pesticide deposition and distribution in apple trees. Plant Dis. 71:613-615.

Turechek, W. W., and Stevenson, K. L. 1998. Effects of host resistance, temperature, leaf wetness, and leaf age on infection and lesion development of pecan scab. Phytopathology 88:1294-1301.

Wells, M. L. 2014. Pecan planting trends in Georgia. HortTechnol. 24:475-479.

Wells, M. L. (ed). 2016 Commercial Pecan Spray Guide. University of Georgia Extension. UGA Extension Bulletin 841.
Wood, B. W. 2009. Mechanical hedge-pruning of pecan in a relatively low-light environment. HortSci. 44:68-72.

Wood, B. W., and Stahmann, D. 2004. Hedge-pruning pecan. HortTechnol. 14 63-72.

Worley, R. E. 1985. Effects of hedging and selective limb pruning of Elliott, Desirable, and Farley pecan trees under three irrigation regimes. J. Am. Soc. Hortic. Sci. 110:12-16.

Worley, R. E., Mullinix, B. G., and Daniel, J. W. 1996. Selective limb pruning, tree removal, and paclobutrazol growth retardant for crowding pecan trees. Sci. Hortic. (Amsterdam) 67:79-85.

Yadav, N. V. S., de Vos, S. M., Bock, C. H., and Wood, B. W. 2013. Development and validation of standard area diagrams to aid assessment of pecan scab symptoms on fruit. Plant Pathol. 62:325-335. 